\title{
Occurrence and Distribution of Physiological Races of Exserohilum turcicum in Ontario, Canada
}

\author{
Krishan K. Jindal, ${ }^{1, \dagger}$ Albert U. Tenuta, ${ }^{2}$ Tsegaye Woldemariam, ${ }^{1}$ Xiaoyang Zhu, $^{1}$ Dave C. Hooker, ${ }^{3}$ and Lana M. Reid ${ }^{1}$ \\ ${ }^{1}$ Ottawa Research and Development Centre, Agriculture and Agri-Food, Ottawa ON, K1A 0C6, Canada \\ ${ }^{2}$ Ontario Ministry of Agriculture, Food and Rural Affairs, ON, NOP 2C0, Canada \\ ${ }^{3}$ University of Guelph, Ridgetown, ON, NOP 2C0, Canada
}

\begin{abstract}
Northern corn leaf blight (NCLB) caused by Exserohilum turcicum is the most common and economically significant fungal leaf disease of corn in Ontario, Canada. During the past 10 years in Ontario, severity and incidence of NCLB have increased, possibly owing to the appearance of new races. Several races have been identified in various parts of the world; however, information on occurrence and distribution of races in Ontario is lacking. In the current study, 677 single conidial isolates of E. turcicum were isolated from 687 symptomatic leaf samples collected between 2012 and 2016. These isolates were evaluated for pathogenicity on six corn differential inbreds (A619, A619Ht1, A619Ht2, A619Ht3, A632Htn 1, and H102Html) under controlled environmental conditions and then grouped into 17 physiological races $(0,1,2,3, \mathrm{M}, \mathrm{N}, 12,1 \mathrm{M}$, $1 \mathrm{~N}, 3 \mathrm{M}, 13 \mathrm{M}, 12 \mathrm{~N}, 13 \mathrm{~N}, 1 \mathrm{MN}, 12 \mathrm{MN}, 13 \mathrm{MN}, 123 \mathrm{MN}$ ) based on the reaction of the inbreds to infection (resistant or susceptible). Four races $(0,1 \mathrm{M}, 1 \mathrm{~N}$, and $1 \mathrm{MN})$ were most frequent, with an isolation frequency of $13,10,12$, and $41 \%$, respectively. Seventy-six percent of the isolates were virulent on more than one $H t$ resistance gene, with $2.4 \%$ (16 iso-

in Ontario. Overall, the frequency of virulence of the 677 isolates screened on the differentials with resistance genes $\mathrm{Ht} 1, \mathrm{Ht} 2, \mathrm{Ht} 3$, $H t m 1$, and $H t n 1$ varied from 6 to $81 \%$ (Ht1 81\%, Ht2 6\%, Ht3 12\%, $\mathrm{Htm} 164 \%$, and $\mathrm{Htn} 164 \%$ ). Virulent isolates produced fewer lesions on the Html differential, and smaller lesions that were slower and having less sporulation on the $\mathrm{Htn} 1$ differential, compared with infection of the differentials with $H t 1, H t 2$, and $H t 3$ resistance genes. Virulence frequency also changed within the four geographical regions of Ontario, with fewer isolates virulent on all resistance genes in eastern Ontario compared with southern and western Ontario. Isolates from southern Ontario had greater virulence frequency against $H t 1$ and $H t m l$, whereas isolates from western Ontario were more frequently virulent on $\mathrm{Htl}$ and $H t n 1$. The information generated in this study on the distribution of $E$. turcicum races in Ontario corn will help growers to select appropriate hybrids with required resistance genes and will assist seed companies in deploying resistance genes in corn hybrids across the province or within a particular region.
\end{abstract} lates) virulent on all five $H t$ resistance genes used in this study. Further analysis of the distribution of races in four regions over the years revealed that the occurrence and distribution of the races changed with time
Keywords: corn, northern corn leaf blight, Exserohilum turcicum, physiological races, virulence, distribution
Northern corn leaf blight (NCLB) caused by Exserohilum turcicum (Passerini) Leonard and Suggs (syn. Setosphaeria turcica [Luttrell] Leonard and Suggs) (Et) is the most common and economically significant leaf disease of corn (Zea mays L.) worldwide including the province of Ontario, Canada (Dong et al. 2008; Jindal et al. 2018; Muiru et al. 2010; Schechert et al. 1999). Disease epidemics were frequent until the discovery and incorporation of the first NCLB-resistance gene, Ht1, into corn hybrids by Hooker in 1963. Since then, many other dominant $(\mathrm{Ht} 2, \mathrm{Ht} 3, \mathrm{Html}, \mathrm{Htn} 1, \mathrm{HtP}$, and $H t N B$ ) and recessive ( $h t 4$ and $r t$ ) NCLB-resistance genes have been discovered, and some of them have been incorporated into corn hybrids (Carson 1995; Galiano-Carneiro and Miedaner 2017; Gevers 1975; Hooker 1977, 1981; Ogliari et al. 2005; Robbins and Warren 1993; Wang et al. 2012; Welz and Geiger 2000). Among all of these

${ }^{\dagger}$ Corresponding author: K. K. Jindal; Krishan.jindal@ canada.ca

Funding: This project was supported by the Agriculture and Agri-Food Canada Growing Forward Partnership with the Canadian Field Crop Research Alliance and the Grain Farmers of Ontario, who obtained funding through "Growing Forward 2" (GF2), a federal-provincial-territorial initiative. The Agricultural Adaptation Council assists in the delivery of GF2 in Ontario.

The author(s) declare no conflict of interest.

Accepted for publication 18 February 2019.

(c) 2019 The American Phytopathological Society resistance genes, $\mathrm{Htl}$ has been the most utilized in commercial corn breeding programs for NCLB control until virulent populations against this gene were reported (Ferguson and Carson 2004; Jordan et al. 1983; Lipps and Hite 1982). Ht2, Ht3, and Htn1 have not been commonly deployed in commercial hybrids owing to variable resistance expression under different environmental temperatures and light intensities (Ferguson and Carson 2004; Leath et al. 1990; Leonard et al. 1989; Thakur et al. 1989b), and the dominant inhibitor gene (Sht1) that is often associated with these genes hinders their transfer into elite germplasm used in backcrossing breeding programs (Ceballos and Gracen 1989; Simcox and Bennetzen 1993). The other dominant and recessive resistance genes, Html (Robbins and Warren 1993), HtP and $r t$ (Ogliari et al. 2005), HtNB (Wang et al. 2012), and $h t 4$ (Carson 1995), also have limited use in corn breeding.

Heavy infections of NCLB before tasseling cause grain yield losses from 28 to $91 \%$ (Ferguson and Carson 2007; Kloppers and Tweer 2009; Nwanosike et al. 2013; Raymundo and Hooker 1981; Wang et al. 2010). Significant losses continue to occur in corn production with planting of highly susceptible inbreds (Mueller et al. 2016). The increased prevalence of NCLB in recent years in the United States and elsewhere has been attributed to many factors, such as changes in the pathogen population (i.e., appearance of new virulent races) (Adipala et al. 1993; Muiru et al. 2010; Pierce 2016; Thakur et al. 1989a; Wang et al. 2011); cultivation practices; and climatic conditions (Mallowa et al. 2015; Wise and Mueller 2011). The province of Ontario has also experienced a surge in NCLB in the past 10 years. Results of annual disease surveys of corn in the main growing 
regions of Ontario over the past 10 years have indicated that the severity and incidence of NCLB have increased particularly during the 2015, 2016, and 2017 crop seasons, when the disease was observed in 97,83 , and $82 \%$ of the fields surveyed (Jindal et al. 2016, 2017, 2018).

Growing resistant hybrids continues to be the most cost-effective and widely used method for NCLB control (Ayiga-Aluba et al. 2015; Ferguson and Carson 2007; Ishfaq et al. 2014; Vieira et al. 2009). The sources of resistance identified to NCLB are qualitative (Hilu and Hooker 1964; Hooker 1961, 1963) or quantitative (Leonard 1993; Pataky et al. 1986). The use of quantitative resistance is always preferred over qualitative because it is more stable and sustainable (Galiano-Carneiro and Miedaner 2017). Continuous surveillance for races of $E t$ even on resistant hybrids with quantitative resistance is important for deploying resistance genes for effective disease management in the field.

The initial identification and designation of $E t$ races was performed by Bergquist and Masias (1974) when they found isolates that were virulent on corn lines with $H t 1$ in Hawaii. They designated these isolates as race 2 to differentiate them from avirulent isolates on corn lines with $H t 1$, which were designated race 1 . Subsequently, isolates virulent on corn with $\mathrm{Ht} 2, \mathrm{Ht} 3$, and $\mathrm{HtN}$ from various parts of the United States were designated as race 2, race 3, and race 4 (Smith and Kinsey 1980; Thakur et al. 1989a; Turner and Johnson 1980). Later on, Leonard et al. (1989) proposed a new system for designation of physiological races of $E t$ based on symptoms on corn inbreds with resistance genes $H t 1, H t 2, H t 3$, and $H t n 1$. Since then, this system has been followed to characterize various isolates of the NCLB pathogen into physiological races. Several studies have used this method to assess local populations of Et, for example, races 0,1 , 2, 23, 2N, and 23N in the United States (Fallah Moghaddam and Pataky 1994; Simcox et al. 1993; Windes and Pedersen 1991); 0, $1,3, \mathrm{~N}, 12,13,23,1 \mathrm{~N}, 2 \mathrm{~N}, 3 \mathrm{~N}, 12 \mathrm{~N}, 23 \mathrm{~N}$, and $123 \mathrm{~N}$ in China (Dong et al. 2008); 23, 2N, and 23N in Mexico; 0, 23, and 23N in Zambia; 0, $1,2,3, \mathrm{~N}$, and $23 \mathrm{~N}$ in Uganda (Welz et al. 1993); 0, 1N, 12N, and $123 \mathrm{~N}$ in Brazil (Gianasi et al. 1996); and 0, 1, 2, 3, N, 12, 13, 23, $3 \mathrm{~N}, 123,13 \mathrm{~N}$, and $23 \mathrm{~N}$ in Kenya, Germany, and Austria (Muiru et al. 2010). In the most recent study, 20 races $(0,1,2, \mathrm{M}, \mathrm{N}, 12$, $13,23,1 \mathrm{M}, 1 \mathrm{~N}, \mathrm{MN}, 123,1 \mathrm{MN}, 2 \mathrm{MN}, 23 \mathrm{M}, 23 \mathrm{~N}, 12 \mathrm{MN}, 23 \mathrm{MN}$, $123 \mathrm{M}$, and $123 \mathrm{MN}$ ) were identified from the north central United States (Weems and Bradley 2018).

Limited information is available on the occurrence, genetic diversity, and geographical distribution of Et race populations in Canada. One report from 2010 identified 23 races of the pathogen recovered from 196 leaf samples with typical NCLB lesions collected in 2005 and 2006, although no individual isolations were made from the leaf samples (Zhu et al. 2010). Because the physiological races of the fungi are closely linked to their ability to cause disease or pathogenicity on the host plant, their identification and distribution across geographical areas are important for disease control and the study of host-pathogen interaction. For example, if the Htl gene confers no resistance to any of the NCLB races found in a particular region, the use of hybrids containing the $\mathrm{Htl}$ gene will be ineffective and may result in significant yield losses in the region; therefore, in the current study, a thorough and systematic approach was undertaken to identify and determine the occurrence and geographical distribution of physiological races of $E t$ in the province of Ontario and to define the reaction of currently available $H t$ resistance genes to the identified races. An understanding of the occurrence and distribution of $E t$ races across Ontario would be useful in plant breeding for screening resistance genes and for developing disease risk management strategies in corn production across the province.

\section{Materials and Methods}

Collection of pathogen isolates. A total of 687 leaf samples (each sample composed of two to six leaves collected from a field visited) with typical NCLB symptoms (long, elliptical, 2 to $15 \mathrm{~cm}$, tan or greyish-green necrotic lesions) were collected from corn plants during annual surveys of commercial grain and silage crops, Ontario Corn Committee hybrid performance trials, breeders' nurseries, commercial demonstration plots, and corn seed production fields, across 27 counties of Ontario in 2012 and in 2014 to 2016. A total of 137 symptomatic leaf samples were collected from 23 counties in 2012, and similarly, 178 from 18 counties in 2014, 186 from 20 counties in 2015, and 168 from 19 counties in 2016. An additional 18 symptomatic leaf samples were collected from the Ottawa Research and Development Center (ORDC) research plots in 2013. Isolations of $E t$ from leaf samples collected within each growing season were made during the subsequent winter months. All racedetermination work was conducted at ORDC, Agriculture and Agri-Food Canada, Ottawa.

In all, 677 isolates were isolated from the 687 leaf samples, which represented 684 individual fields. Isolations were made by cutting a small sample $(3 \times 4 \mathrm{~mm})$ of the leaf along the advancing margin of the disease lesions and surface sterilizing the sample with $2 \%$ sodium hypochlorite solution for $2 \mathrm{~min}$. The leaf tissue samples were washed in sterile distilled water, plated onto potato dextrose agar (PDA) medium (39 $\mathrm{g}$ of Difco PDA in 1 liter of water) in 100- $\times 15-\mathrm{mm}$ polystyrene Petri dishes, and then incubated at a temperature of $23 \pm 2{ }^{\circ} \mathrm{C}$ for 10 to 12 days. A pure culture was obtained by subculturing the leading edge of the fungal colony that grew from the leaf tissue sample onto PDA. To obtain single conidial cultures, the pure culture grew for 10 to 15 days at $25^{\circ} \mathrm{C}$ until it sporulated. The spores were gently washed from the culture, and a dilute conidial suspension was spread onto water agar ( $10 \mathrm{~g}$ of agar and 1 liter of water) to obtain single-colony isolates. After 12 to $24 \mathrm{~h}$ of incubation at $23 \pm 2^{\circ} \mathrm{C}$, separable germinating conidia were identified and marked using a zoom 20x stereomicroscope (Wild Heerbrugg AG, Switzerland) at a working distance of $25 \mathrm{~mm}$ (total magnification $80 \times$ ). Marked conidia were transferred onto sterilized PDA medium using a sterile inoculation needle and stored on PDA in a refrigerator at 2 to $4{ }^{\circ} \mathrm{C}$ until further analysis.

Race determination. Six differential lines (A619 [P1587139], A619Ht1 [Ames 25219], A619Ht2 [Ames 25220], A619Ht3 [Ames 25221], H102Html [PI 550496], and A632Htnl [Ames 23469]) obtained from the United States Department of Agriculture, Agricultural Research Service (https://www.ars-grin.gov/npgs/index.html) (North Central Regional Plant Introduction Station, Iowa State University, Regional Plant Protection Station, Ames, IA, U.S.A.) were used for the identification of physiological races of Et. Plastic planting pots $25 \mathrm{~cm}$ in diameter were filled with a mixture of Pro-Mix 'BX' (Premier Horticulture, Riviera-du-Loup, QC, Canada). Three seeds per line of three differentials (total nine seeds) were planted in pot A (A619, A619Ht1, and A619Ht2) and pot B (A619Ht3, $\mathrm{H} 102 \mathrm{Htm}$, and A632Htn 1). The line A619 served as a positive control to verify successful inoculation and disease development. If all three seedlings emerged in one pot, one plant was removed, and the remaining two plants of each differential line served as two replicates for each $E t$ isolate. Two plants of each differential were inoculated with a single $E t$ isolate to be characterized. Preliminary studies conducted in an environmentally controlled greenhouse compared NCLB development and plant growth in growth cabinets at two temperatures: $26 / 22^{\circ} \mathrm{C}$ day/night and $22 / 18^{\circ} \mathrm{C}$ day/night, at light intensities of 35 to 50 Klux. The latter showed the most consistent NCLB development; thus, plant growth cabinets in the present study for screening isolates were maintained $22 / 18^{\circ} \mathrm{C}$ day/night with light intensities between 35 to 50 Klux (40 Klux) for 16/8-h day/night similar to that used by Leonard et al. (1989).

Isolates of $E t$ to be characterized were multiplied from the first generation of single conidial cultures stored in a refrigerator at 2 to $4^{\circ} \mathrm{C}$ on PDA. The cultures were grown on PDA at $25^{\circ} \mathrm{C}$ for 10 to 12 days under 12-h light/dark regimes to induce sporulation, and the conidia were displaced from the surface with a sterile glass slide and removed with sterile water. This conidial suspension was filtered through a double layer of sterile cheese cloth, the conidia were counted with a hemocytometer, and the suspension diluted to $1 \times$ $10^{4}$ conidia/ml. Two drops of Tween 20 (polyoxyethylenesorbitan monolaurate) were added to the conidial suspension, and $0.2 \mathrm{ml}$ of the conidial suspension was pipetted with micropipettes into the leaf whorl of corn seedlings at V4 to V6 stage. Inoculated plants were 
incubated in the plant growth cabinets maintained at $22^{\circ} \mathrm{C}$ day $/ 18^{\circ} \mathrm{C}$ night and light intensities between 35 and 50 Klux ( 16 h daytime and $8 \mathrm{~h}$ nighttime), similar to that used by Leonard et al. (1989).

Differentials were examined for NCLB symptoms 14 days after inoculation, and lesions were scored based on their appearance as resistant (narrow chlorotic lesions surrounded by yellowish chlorosis with no sporulation) or susceptible (straw-colored, olive-green, necrotic elliptical lesions without chlorotic border and with sporulation). Lesion size, number of lesions, and sporulation were also recorded to further understand the infection response of the five differentials to inoculation with test isolates. Resistant and susceptible lesions from each differential and replicate were evaluated for length and width of each lesion and sporulation. One 6-mm disk was cut with a paper hole punch from the center of each lesion. Three leaf disks from each differential replicate were placed into $9-\mathrm{cm}$ Petri plates containing $10 \mathrm{ml}$ of cornmeal agar medium without surface sterilization. The leaf disks were then incubated at 24 to $26^{\circ} \mathrm{C}$ with a 12 -h light/dark cycle in a culture room to observe sporulation. After $24 \mathrm{~h}, 5 \mathrm{ml}$ of distilled water was added to each Petri plate and swirled around the surface to wash out any conidia. The conidia were counted in $1 \mathrm{ml}$ of the resulting conidial suspension on a Spencer Bright-Line improved counting chamber with improved Neubauer $1 / 10 \mathrm{~mm}$ deep slide 13 (U.S. patent no. 2.660.091) under a light microscope. The race of isolates was determined using the race scheme outlined by Leonard et al. (1989) with one additional resistance gene, Html, as described in Table 1, to further characterize the isolates. Representative cultures of identified races were deposited in the Canadian Collection of Fungal Cultures, ORDC, Ottawa, Canada, for future use.

Frequency and distribution of isolates of each race, isolates' virulence complexity (number of $H t$ resistance genes with which an isolate has a susceptible response), virulence frequency of isolates to $\mathrm{Ht}$ resistance genes, and three commonly used diversity indices (the simple, Gleason, and Shannon indices) were calculated using the formulas presented by Groth and Roelfs (1987) and compared among regions and years.

\section{Results}

A total of 677 isolates (14 from central, 64 from eastern, 292 from southern, and 107 from western Ontario) were obtained from the leaf samples collected from 684 fields visited across Ontario between 2012 and 2016. These isolates produced small, pinhead-sized chlorotic lesions 48 to $72 \mathrm{~h}$ after inoculation on corn plants. Clear resistant and susceptible reactions became apparent 10 to 12 days after inoculation. Based on the infection reaction (resistant or susceptible) of the isolates on the five differentials, the 677 isolates were divided into 17 physiological races $(0,1,2,3, \mathrm{M}, \mathrm{N}, 12,1 \mathrm{M}, 1 \mathrm{~N}, 3 \mathrm{M}, 12 \mathrm{~N}$, $13 \mathrm{M}, 13 \mathrm{~N}, 1 \mathrm{MN}, 12 \mathrm{MN}, 13 \mathrm{MN}$, and 123NM). Resistance responses were observed on all the differential plants with $H t$ resistance genes on inoculation with an avirulent isolate. Resistance responses on differential lines with $\mathrm{Htl}, \mathrm{Ht} 2, \mathrm{Ht} 3$, and $\mathrm{Htnl}$ were characterized by prominent chlorosis around elongated necrotic lesions of size $3.3 \pm$ $1.3 \mathrm{~cm}$ long and $0.4 \pm 0.1 \mathrm{~cm}$ wide in the center). The $\mathrm{Html}$ resistance

Table 1. Designation of physiological races of Exserohilum turcicum on the basis of their infection reaction on five differentials with different $H t$ resistance genes

\begin{tabular}{lcccccc}
\hline \multirow{2}{*}{$\begin{array}{l}\text { Race } \\
\text { designation }\end{array}$} & \multicolumn{6}{c}{ Response $^{\mathbf{a}}$} \\
\cline { 2 - 7 } & A619 & A619Ht1 & A619Ht2 & A619Ht3 & Ht102Htm1 & A632HtnI \\
\hline 0 & $\mathrm{~S}$ & $\mathrm{R}$ & $\mathrm{R}$ & $\mathrm{R}$ & $\mathrm{R}$ & $\mathrm{R}$ \\
1 & $\mathrm{~S}$ & $\mathrm{~S}$ & $\mathrm{R}$ & $\mathrm{R}$ & $\mathrm{R}$ & $\mathrm{R}$ \\
2 & $\mathrm{~S}$ & $\mathrm{R}$ & $\mathrm{S}$ & $\mathrm{R}$ & $\mathrm{R}$ & $\mathrm{R}$ \\
12 & $\mathrm{~S}$ & $\mathrm{~S}$ & $\mathrm{~S}$ & $\mathrm{R}$ & $\mathrm{R}$ & $\mathrm{R}$ \\
23 & $\mathrm{~S}$ & $\mathrm{R}$ & $\mathrm{S}$ & $\mathrm{S}$ & $\mathrm{R}$ & $\mathrm{R}$ \\
$23 \mathrm{~N}$ & $\mathrm{~S}$ & $\mathrm{R}$ & $\mathrm{S}$ & $\mathrm{S}$ & $\mathrm{R}$ & $\mathrm{S}$ \\
$123 \mathrm{MN}$ & $\mathrm{S}$ & $\mathrm{S}$ & $\mathrm{S}$ & $\mathrm{S}$ & $\mathrm{S}$ & $\mathrm{S}$ \\
\hline
\end{tabular}

${ }^{a} \mathrm{R}=$ resistant (narrow chlorotic lesions surrounded by chlorosis, chlorotic fleck-like lesions with little or no necrosis and sporulation); and $\mathrm{S}=$ susceptible (straw-colored, olive-green, necrotic elliptical lesions without chlorotic border and with a lot of sporulation). response was characterized by fewer lesions $(1.6 \pm 0.6$ lesion per leaf on the differential with $H t m l$ compared with $4.5 \pm 1.5$ on the differentials with other resistance genes) with almost no prominent chlorosis.

Three-quarters of the 677 isolates belonged to four predominant races: race $1 \mathrm{MN}$ (274 isolates, $40.5 \%)$, race 0 ( 85 isolates, $12.6 \%$ ), race $1 \mathrm{~N}$ (79 isolates, $11.7 \%$ ), and race $1 \mathrm{M}$ (70 isolates, $10.3 \%)$. Sixteen isolates $(2.8 \%)$ were virulent on all differentials and were consequently designated as race $123 \mathrm{MN}$ (Table 2).

Geographic distribution and frequency of occurrence of races of $\boldsymbol{E} \boldsymbol{t}$. The frequencies of identified races were not consistent across the years. Nine races $(1, \mathrm{~N}, 1 \mathrm{M}, 3 \mathrm{M}, 13 \mathrm{M}, 1 \mathrm{MN}, 12 \mathrm{MN}, 13 \mathrm{MN}$, and $123 \mathrm{MN})$ were common among all symptomatic leaf samples collected in all years (2012 to 2016). Among these, race $1 \mathrm{MN}$ was the most frequently isolated race in four of five years; race $1 \mathrm{~N}$ was the most frequent in 2015. Race 2 was recovered only in 2015 and 2016, and race 12 was recovered only in 2012 and 2016. The second most common and widespread race was $1 \mathrm{M}$ in 2012 and 2014, race $1 \mathrm{MN}$ in 2015, and race 0 in 2016 (Table 2).

Race populations also varied within and among each region from 2012 to 2016 (Table 3). Over five years, all 17 races were recovered from the leaf samples collected from southern Ontario, 16 from eastern Ontario, 12 from western Ontario, and 7 from central Ontario. Seven races $(1, \mathrm{~N}, 1 \mathrm{M}, 13 \mathrm{~N}, 1 \mathrm{MN}, 13 \mathrm{MN}$, and $123 \mathrm{MN})$ were identified from all four regions. Five races $(2,3, \mathrm{M}, 3 \mathrm{M}$, and $13 \mathrm{M})$ were identified only from leaf samples collected from southern and eastern Ontario. Race $123 \mathrm{MN}$ was detected in nine inbred leaf samples from southern Ontario seed corn fields. The second most prevalent race was race 0 in eastern and southern Ontario and race $1 \mathrm{~N}$ in western Ontario. The third most predominant races were $1 \mathrm{M}, 1 \mathrm{~N}$, and 1 in eastern, southern, and western Ontario, respectively. Frequency of occurrence of races also varied within and across counties from 2012 to 2016. Race 0 was found in 12 counties of eastern, southern, and western Ontario, whereas race $1 \mathrm{~N}$ was found in 15 , race $1 \mathrm{M}$ in 18 , and race $1 \mathrm{MN}$ in 23 out of the 27 counties sampled. Race 3 was identified in three counties, race $3 \mathrm{M}$ and race 12 in four counties, race 2 in five counties, and race $M$ in six counties sampled (Table 3 ). The Et population was very complex. Seventy-six percent of screened isolates were virulent on multiple $H t$ resistance genes and $52.2 \%$ on three or more genes. One-tenth of the isolates were extremely virulent on four or more $H t$ genes screened (Fig. 1). Isolates with virulence to one $H t$ gene were observed as often as race 0 .

The population of $E t$ recovered from leaf samples collected from the central region of Ontario had the greatest simple diversity (ratio of races to isolates sampled); the southern region had the highest Gleason (indicating richness of races) and the eastern region the highest Shannon indices (indicating evenness of race distribution within a region) of diversity (Table 4). Among years, the simple diversity index was greatest in 2014, whereas the greatest Gleason (indicating race richness) and Shannon indices (indicating evenness of race distribution with a region) of diversity values were observed in 2015.

Frequency of virulence of isolates on specific $\mathrm{Ht}$ genes. The frequency of virulence to the specific $H t$ genes tested in this study was compared across years and regions for all 677 isolates. Overall, the frequency of virulence of the isolates screened varied from 6 to $81 \%$. A total of $81 \%$ of the isolates were virulent on the differential line with the resistance gene $H t 1$. The frequency of virulence of the isolates on the resistance genes $\mathrm{Htm} 1$ and $\mathrm{Htn} 1$ was $64 \%$ for both genes. On average, virulent isolates produced $40 \pm 15 \%$ fewer lesions on the Html differential compared with the differentials with $\mathrm{Htl}$, $\mathrm{Ht} 2$, and $\mathrm{Ht} 3$ resistance genes (data not given). Moreover, the Htn $\mathrm{l}$ differential infection by virulent isolates resulted in $25 \pm 9.5 \%$ smaller lesions that were slower (4 to 5 days) to develop and had $40 \pm 11 \%$ less sporulation compared with infection of the differentials with $H t 1, H t 2$, and $H t 3$ resistance genes. There were fewer isolates (6 and 12\%) recovered that were virulent on differentials with the resistance gene $H t 2$ and $H t 3$, respectively. The frequency of virulence on $H t$ resistance gene differentials also varied within and across the years. Fewer isolates were virulent on the Html 
differential in 2015 compared with 2012 and 2014, and fewer isolates were virulent on the Htnl differential in 2012 compared with 2014 and 2015. Temporal variation was also observed among the number of isolates virulent in all the years, with fewer isolates virulent on the
Ht1, Html, and Htnl differentials in 2016 compared with 2014 (Table 5).

The frequency of the virulence of isolates on the differentials with $\mathrm{Ht}$ genes also varied within and across four regions of Ontario. The

Table 2. Frequency of Exserohilum turcicum isolates of each race in Ontario corn within and across years

\begin{tabular}{|c|c|c|c|c|c|c|c|}
\hline \multirow[b]{2}{*}{ Race } & \multicolumn{5}{|c|}{ Number of isolates } & \multirow[b]{2}{*}{ Per race $(\%)$} & \multirow[b]{2}{*}{ DAOMC numbera } \\
\hline & 2012-13 & 2014 & 2015 & 2016 & All years & & \\
\hline 0 & 0 & 16 & 26 & 43 & 85 & 12.6 & 250602,250761 \\
\hline 1 & 18 & 7 & 12 & 6 & 43 & 6.4 & 250603,250762 \\
\hline 2 & 0 & 0 & 2 & 7 & 9 & 1.3 & 251774 \\
\hline 3 & 0 & 1 & 4 & 0 & 5 & 0.7 & $250605,250783,250784$ \\
\hline M & 0 & 12 & 1 & 2 & 15 & 2.2 & 251773 \\
\hline $\mathrm{N}$ & 1 & 1 & 1 & 4 & 7 & 1.0 & 250787,250788 \\
\hline 12 & 3 & 0 & 0 & 1 & 4 & 0.6 & 251775 \\
\hline $1 \mathrm{M}$ & 40 & 20 & 8 & 2 & 70 & 10.3 & 250777 \\
\hline $1 \mathrm{~N}$ & 0 & 8 & 55 & 16 & 79 & 11.7 & $250604,250778,250779$ \\
\hline $3 \mathrm{M}$ & 1 & 1 & 2 & 1 & 5 & 0.7 & 250785,250786 \\
\hline $12 \mathrm{~N}$ & 0 & 1 & 1 & 0 & 2 & 0.3 & 250765,250766 \\
\hline $13 \mathrm{M}$ & 4 & 1 & 1 & 1 & 7 & 1.0 & $250769,250770,250771$ \\
\hline $13 \mathrm{~N}$ & 0 & 1 & 3 & 4 & 8 & 1.2 & 250772,250773 \\
\hline $1 \mathrm{MN}$ & 70 & 90 & 51 & 63 & 274 & 40.5 & $250780,250781,250782$ \\
\hline $12 \mathrm{MN}$ & 3 & 5 & 2 & 1 & 11 & 1.6 & 250767,250768 \\
\hline $13 \mathrm{MN}$ & 7 & 6 & 12 & 12 & 37 & 5.5 & $250674,250675,250676$ \\
\hline $123 \mathrm{MN}$ & 4 & 5 & 3 & 4 & 16 & 2.4 & 250763,250764 \\
\hline All races & 151 & 175 & 184 & 167 & 677 & & \\
\hline
\end{tabular}

${ }^{\text {a }}$ Representative samples were submitted to the Department of Agriculture, Ottawa, Mycology Collection (DAOMC) repository.

Table 3. Frequency and distribution of Exserohilum turcicum isolates of each race within and across regions of Ontario corn

\begin{tabular}{|c|c|c|c|c|c|c|c|c|c|c|c|c|c|c|c|c|c|c|c|}
\hline \multirow[b]{2}{*}{ Region, county } & \multirow[b]{2}{*}{ Number of races } & \multicolumn{17}{|c|}{ Number of isolates } & \multirow[b]{2}{*}{ All races } \\
\hline & & $\mathbf{0}$ & 1 & 2 & 3 & $\mathbf{M}$ & $\mathbf{N}$ & 12 & $\mathbf{1 M}$ & $1 \mathbf{N}$ & $3 \mathrm{M}$ & $12 \mathrm{~N}$ & 13M & $13 N$ & $1 \mathrm{MN}$ & $12 \mathrm{MN}$ & $13 \mathrm{MN}$ & $123 \mathrm{MN}$ & \\
\hline \multicolumn{20}{|l|}{ Central Ontario } \\
\hline Durham & 7 & $\ldots$ & 1 & $\ldots$ & $\ldots$ & $\ldots$ & 1 & $\ldots$ & 2 & $\ldots$ & $\ldots$ & $\ldots$ & $\ldots$ & 1 & 3 & $\ldots$ & 1 & 1 & 10 \\
\hline Northumberland & 1 & $\ldots$ & $\ldots$ & $\ldots$ & $\ldots$ & $\ldots$ & $\ldots$ & $\ldots$ & 1 & $\ldots$ & $\ldots$ & $\ldots$ & $\ldots$ & $\ldots$ & $\ldots$ & $\ldots$ & $\ldots$ & $\ldots$ & 1 \\
\hline Peterborough & 1 & $\ldots$ & $\ldots$ & $\ldots$ & $\ldots$ & $\ldots$ & $\ldots$ & $\ldots$ & $\ldots$ & $\ldots$ & $\ldots$ & $\ldots$ & $\ldots$ & $\ldots$ & 1 & $\ldots$ & $\ldots$ & $\ldots$ & 1 \\
\hline York & 1 & $\ldots$ & $\ldots$ & $\ldots$ & $\ldots$ & $\ldots$ & $\ldots$ & $\ldots$ & $\ldots$ & $\ldots$ & $\ldots$ & $\ldots$ & $\ldots$ & $\ldots$ & - & $\ldots$ & 1 & $\ldots$ & 1 \\
\hline Victoria & 1 & $\ldots$ & $\ldots$ & $\ldots$ & $\ldots$ & $\ldots$ & $\ldots$ & $\ldots$ & $\ldots$ & $\ldots$ & $\ldots$ & $\ldots$ & $\ldots$ & $\ldots$ & 1 & $\ldots$ & $\ldots$ & $\ldots$ & 1 \\
\hline Total for region & 7 & $\ldots$ & 1 & $\ldots$ & $\ldots$ & $\ldots$ & 1 & $\ldots$ & 3 & $\ldots$ & $\ldots$ & $\ldots$ & $\ldots$ & 1 & 5 & $\ldots$ & 2 & 1 & 14 \\
\hline \multicolumn{20}{|l|}{ Eastern Ontario } \\
\hline Frontenac & 4 & 1 & $\ldots$ & $\ldots$ & $\ldots$ & $\ldots$ & $\ldots$ & $\ldots$ & 2 & $\ldots$ & $\ldots$ & $\ldots$ & $\ldots$ & $\ldots$ & 1 & $\ldots$ & 1 & $\ldots$ & 5 \\
\hline Hastings & 3 & $\ldots$ & $\ldots$ & 1 & $\ldots$ & $\ldots$ & $\cdots$ & $\ldots$ & 1 & $\ldots$ & 1 & $\ldots$ & $\ldots$ & $\ldots$ & $\ldots$ & $\ldots$ & $\ldots$ & $\ldots$ & 3 \\
\hline Lanark & 3 & $\ldots$ & $\ldots$ & $\ldots$ & $\ldots$ & $\ldots$ & $\ldots$ & 1 & $\ldots$ & 5 & $\ldots$ & $\ldots$ & $\ldots$ & $\ldots$ & 2 & $\ldots$ & $\ldots$ & $\ldots$ & 8 \\
\hline Leeds and Grenville & 7 & 2 & 1 & $\ldots$ & $\ldots$ & $\ldots$ & 1 & $\ldots$ & 6 & $\ldots$ & $\ldots$ & $\ldots$ & $\ldots$ & 3 & 11 & 1 & $\ldots$ & $\ldots$ & 25 \\
\hline Ottawa & 13 & 37 & 4 & 5 & 2 & 3 & $\ldots$ & $\ldots$ & 11 & 13 & 2 & $\ldots$ & 2 & $\ldots$ & 39 & 1 & 3 & 4 & 126 \\
\hline Prescott and Russell & 7 & 2 & 1 & 1 & $\ldots$ & $\ldots$ & $\ldots$ & $\ldots$ & 4 & 6 & $\ldots$ & $\ldots$ & $\ldots$ & $\ldots$ & 5 & $\ldots$ & 1 & $\ldots$ & 20 \\
\hline Renfrew & 4 & $\ldots$ & 6 & & $\ldots$ & $\ldots$ & $\ldots$ & $\ldots$ & 2 & 1 & $\ldots$ & $\ldots$ & $\ldots$ & $\ldots$ & 12 & $\ldots$ & $\ldots$ & $\ldots$ & 21 \\
\hline SDG & 11 & 7 & 4 & 1 & $\ldots$ & 1 & 1 & $\ldots$ & 13 & 6 & $\ldots$ & $\ldots$ & 2 & $\ldots$ & 17 & 1 & 3 & $\ldots$ & 56 \\
\hline Total for region & 16 & 49 & 16 & 8 & 2 & 4 & 2 & 1 & 39 & 31 & 3 & $\ldots$ & 4 & 3 & 87 & 3 & 8 & 4 & 264 \\
\hline \multicolumn{20}{|l|}{ Southern Ontario } \\
\hline Chatham-Kent & 14 & 19 & 9 & $\ldots$ & 2 & 6 & 3 & 1 & 8 & 14 & 1 & $\ldots$ & 2 & $\ldots$ & 56 & 1 & 11 & 5 & 138 \\
\hline Elgin & 10 & 7 & 3 & $\ldots$ & $\ldots$ & 2 & $\ldots$ & $\ldots$ & 3 & 1 & 1 & $\ldots$ & 1 & $\ldots$ & 22 & $\cdots$ & 4 & 1 & 45 \\
\hline Essex & 4 & $\ldots$ & $\ldots$ & $\ldots$ & 1 & $\ldots$ & $\ldots$ & $\ldots$ & $\ldots$ & 4 & $\ldots$ & $\ldots$ & $\ldots$ & $\ldots$ & 11 & $\ldots$ & $\ldots$ & 2 & 18 \\
\hline Lambton & 4 & $\ldots$ & 1 & $\ldots$ & $\ldots$ & $\ldots$ & $\cdots$ & $\ldots$ & 3 & $\ldots$ & $\ldots$ & $\ldots$ & $\ldots$ & $\ldots$ & 5 & 1 & $\ldots$ & $\ldots$ & 10 \\
\hline Middlesex & 10 & 4 & $\ldots$ & $\ldots$ & $\ldots$ & 2 & $\ldots$ & 1 & 6 & 6 & $\ldots$ & $\ldots$ & $\ldots$ & 1 & 17 & 2 & 2 & 1 & 42 \\
\hline Norfolk & 1 & $\ldots$ & $\ldots$ & $\ldots$ & $\ldots$ & $\ldots$ & $\ldots$ & $\ldots$ & $\ldots$ & $\ldots$ & $\ldots$ & $\ldots$ & $\ldots$ & $\ldots$ & 4 & $\ldots$ & $\ldots$ & $\ldots$ & 4 \\
\hline Oxford & 9 & 1 & 3 & 1 & $\ldots$ & 1 & $\ldots$ & $\ldots$ & 2 & 3 & $\ldots$ & 1 & $\ldots$ & $\ldots$ & 18 & 1 & 3 & $\ldots$ & 34 \\
\hline Simcoe & 1 & $\ldots$ & $\ldots$ & & $\ldots$ & $\ldots$ & $\ldots$ & $\ldots$ & $\ldots$ & $\ldots$ & $\ldots$ & $\ldots$ & $\ldots$ & $\ldots$ & 1 & $\ldots$ & $\ldots$ & $\ldots$ & 1 \\
\hline Total for region & 17 & 31 & 16 & 1 & 3 & 11 & 3 & 2 & 22 & 28 & 2 & 1 & 3 & 1 & 134 & 5 & 20 & 9 & 292 \\
\hline \multicolumn{20}{|l|}{ Western Ontario } \\
\hline Dufferin & 5 & 1 & 1 & $\ldots$ & $\ldots$ & $\ldots$ & $\ldots$ & $\ldots$ & 1 & $\ldots$ & $\ldots$ & $\ldots$ & $\ldots$ & $\ldots$ & 7 & $\ldots$ & 1 & $\ldots$ & 11 \\
\hline Gray & 2 & $\ldots$ & $\ldots$ & $\ldots$ & $\ldots$ & $\ldots$ & $\ldots$ & $\ldots$ & $\ldots$ & 1 & $\ldots$ & $\ldots$ & $\ldots$ & 1 & $\ldots$ & $\ldots$ & $\ldots$ & $\ldots$ & 2 \\
\hline Huron & 8 & 1 & 5 & $\ldots$ & $\ldots$ & $\ldots$ & $\ldots$ & $\ldots$ & 1 & 2 & $\ldots$ & $\ldots$ & $\ldots$ & 1 & 16 & 1 & 3 & $\ldots$ & 30 \\
\hline Perth & 7 & 3 & $\ldots$ & $\ldots$ & $\ldots$ & $\ldots$ & 1 & $\ldots$ & $\ldots$ & 11 & $\ldots$ & $\ldots$ & $\ldots$ & $\ldots$ & 13 & 1 & 2 & 2 & 33 \\
\hline Waterloo & 4 & $\ldots$ & 2 & $\ldots$ & $\ldots$ & $\ldots$ & $\ldots$ & $\ldots$ & 3 & 3 & $\ldots$ & $\ldots$ & $\ldots$ & $\ldots$ & 7 & $\ldots$ & $\ldots$ & $\ldots$ & 15 \\
\hline Wellington & 8 & $\ldots$ & 2 & $\ldots$ & $\ldots$ & $\ldots$ & $\ldots$ & 1 & 1 & 3 & $\ldots$ & 1 & $\ldots$ & 1 & 5 & 1 & 1 & $\ldots$ & 16 \\
\hline Total for region & 12 & 5 & 10 & $\ldots$ & $\ldots$ & $\ldots$ & 1 & 1 & 6 & 20 & $\ldots$ & 1 & $\ldots$ & 3 & 48 & 3 & 7 & 2 & 107 \\
\hline
\end{tabular}


frequency of virulence for the isolates from the eastern Ontario region was lowest on the $\mathrm{Htl}, \mathrm{Ht} 2, \mathrm{Ht} 3$, and $\mathrm{Htnl}$ differentials compared with the isolates from the central, southern, and western Ontario regions (Table 6). The frequency of virulence of the isolates on $\mathrm{Htl}$ differential was $>70 \%$ in all the regions, with a maximum frequency of $94 \%$ for the western Ontario isolates. In contrast to $H t 1$, the frequency of virulence of the isolates on $\mathrm{Ht} 2$ differential was approximately $6 \%$ in all the regions, with a maximum frequency of $7 \%$ again for the western Ontario isolates. The frequency of virulence of the isolates on $\mathrm{Ht} 3$ differential ranged from $9 \%$ to a maximum of $29 \%$ in the central Ontario isolates. The frequency of virulence of the isolates on $\mathrm{Htm} \mathrm{l}$ and $\mathrm{Htnl}$ differentials was $>50 \%$ in all the regions, with a maximum frequency of $71 \%$ on $\mathrm{Html}$ differential for the southern Ontario isolates and $79 \%$ on Htnl for the western Ontario isolates (Table 6). Of the isolates tested in this study, $13 \%$ were avirulent to all $\mathrm{Ht}$ genes, $81 \%$ were virulent to $H t 1,6 \%$ were to $H t 2,12 \%$ were to $H t 3,64 \%$ were to $H t m l$, and $64 \%$ were to Htn1 differentials.

\section{Discussion}

In this study, we identified 17 races from the leaf samples collected from Ontario, with races $0,1 \mathrm{M}, 1 \mathrm{~N}$, and $1 \mathrm{MN}$ being the most prevalent. Zhu et al. (2010) identified 25 races from leaf samples collected from Ontario and Quebec in 2006 and 2007 using the same set of five differentials with, races $0,1,3,23$, and $23 \mathrm{M}$ being the most prevalent. In this study, five races (N, 12N, 13N, 12MN, and 123MN) were identified for the first time in Canada, and 10 races $(13,23,2 \mathrm{M}, 3 \mathrm{~N}$, $12 \mathrm{M}, 23 \mathrm{M}, 23 \mathrm{~N}, 3 \mathrm{NM}, 23 \mathrm{NM}$, and $123 \mathrm{M}$ ) that were previously identified from Ontario and Quebec leaf samples (Zhu et al. 2010) were not detected. Detection of the race $123 \mathrm{MN}$ in this study, which was virulent on all five resistance genes, suggests that current

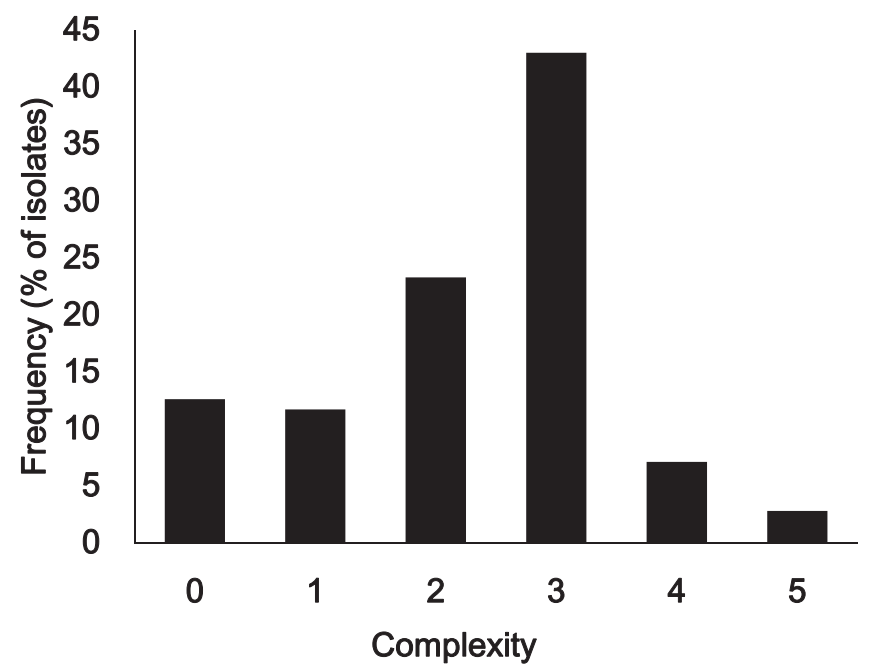

Fig. 1. The complexity of Exserohilum turcicum isolates collected from Ontario corn between 2012 and 2016, denoted by the number of differential lines with which a specific isolate produced a susceptible response. commercial hybrids may eventually become susceptible to changing NCLB populations in Ontario. The predominance of races $0,1 \mathrm{M}, 1 \mathrm{~N}$, and $1 \mathrm{MN}$, compared with races $2,3, \mathrm{~N}, 3 \mathrm{M}, 12 \mathrm{~N}, 13 \mathrm{M}, 13 \mathrm{~N}$, and $12 \mathrm{MN}$ in the current study is similar to earlier studies, which reported that races 0,1 , and $1 \mathrm{~N}$ were predominant in North America and other races such as $2 \mathrm{~N}$ and $23 \mathrm{~N}$ were less prevalent (Bergquist and Masias 1974; Fallah Moghaddam and Pataky 1994; Jordan et al. 1983; Lipps and Hite 1982; Pieczarka 1980; Smith and Kinsey 1980; Thakur et al. 1989a; Windes and Pedersen 1991; Weems and Bradley 2018). Races $1 \mathrm{M}$ and $1 \mathrm{MN}$ in this study are equivalent to races 1 and $1 \mathrm{~N}$ found in the earlier studies with four differentials for race differentiation.

The change in race structure over time has also been previously reported in other locations such as Africa, China, Europe, and the United States (Dong et al. 2008; Ferguson and Carson 2007; Ji et al. 2013; Jordan et al. 1983; Krausz et al. 1993; Muiru et al. 2010; Pierce 2016; Weems and Bradley 2018). Change in the race structure of the Et population has been attributed to changes in cultivation practices, hybrids, and/or climate over time (Mallowa et al. 2015; Wise and Mueller 2011). The change in race structure can also be attributed to the source of leaf samples used for isolation in this study Zhu et al. (2010).

Multiple races being found within and between fields, counties, or regions over the 5 years demonstrates that a high diversity of races are present in the province. Some races found in one county or region were not found in other counties or regions within a year. Multiple races were also found within corn fields. This was observed at the ORDC research farm breeding nursery. Five races were identified from 18 NCLB-symptomatic leaf samples collected from the ORDC research farm in 2013. The population of $E t$ in a breeding nursery is likely to be more diverse compared with the population of the pathogen in most commercial fields owing to the large diversity of host genotypes and a predominance of inbreds versus hybrids. Some variation in race diversity among regions and years observed in this study may be the result of isolates collected from different fields within a county or region and the hybrids in each year. These variations in source of isolates (leaf sampling) made it difficult to draw a clear comparison between population diversity across regions and years. However, the high race diversity in this collection does suggest a genetically diverse population within regions and years. This diversity may be attributed to (i) sexual recombination and mutation of existing races (Bunkoed et al. 2014; Ferguson and Carson 2004), (ii) selection pressure linked to physiological races owing to cultivation of different hybrids in different areas or a few hybrids grown in a large area (Galiano-Carneiro and Miedaner 2017), and (iii) a long-distance dispersal of spores between counties (Ferguson and Carson 2004). Others have hypothesized similar reasons to explain the change in race diversity, both temporally and spatially, for other corn growing regions of the world (Carson 2006; Weems and Bradley 2018; Welz and Geiger 2000). The increase in virulence frequency with race complexity (virulence to multiple $H t$ genes) observed in this study suggests possible fitness penalties associated with virulence genes. The diversity indices presented in the current study helped to understand the race population distribution across

Table 4. Diversity indices of Exserohilum turcicum populations across regions and years

\begin{tabular}{|c|c|c|c|c|c|c|}
\hline \multirow[b]{2}{*}{ Region/year } & \multirow[b]{2}{*}{ Number of counties } & \multirow[b]{2}{*}{ Number of isolates } & \multirow[b]{2}{*}{ Number of races } & \multicolumn{3}{|c|}{ Indices of diversity ${ }^{a}$} \\
\hline & & & & Simple & Gleason & Shannon \\
\hline Central region & 5 & 14 & 7 & 0.500 & 2.27 & 1.72 \\
\hline Eastern region & 8 & 264 & 16 & 0.061 & 2.69 & 2.03 \\
\hline Southern region & 8 & 292 & 17 & 0.058 & 2.82 & 1.93 \\
\hline Western region & 6 & 107 & 12 & 0.112 & 2.35 & 1.78 \\
\hline $2012-13$ & 23 & 151 & 10 & 0.066 & 1.79 & 1.51 \\
\hline 2014 & 18 & 175 & 15 & 0.086 & 2.71 & 1.76 \\
\hline 2015 & 20 & 184 & 16 & 0.087 & 2.88 & 1.96 \\
\hline 2016 & 19 & 167 & 15 & 0.090 & 2.74 & 1.88 \\
\hline Total & 27 & 677 & 17 & 0.025 & 2.45 & 2.01 \\
\hline
\end{tabular}

${ }^{a}$ Diversity indices calculated using the formulas given in Groth and Roelfs (1987). 
regions and years; however, these are affected by the number and distribution of fields sampled and by the isolates obtained from each region and year; thus, the distribution should be considered carefully. In the current study, sampling more fields and testing more isolates from within a region or within a year resulted in observation of more races. For example, the southern region had the largest sample size and maximum number of races.

Races $1 \mathrm{~N}$ and $1 \mathrm{MN}(1 \mathrm{~N}$ in earlier studies) were the most frequently observed and widely distributed races across Ontario, which is similar to observations reported by Ferguson and Carson (2007), who recovered a single race $(1 \mathrm{~N})$ from most NCLB-symptomatic leaf samples collected from the eastern states of the United States. Race 1 ( 1 and $1 \mathrm{M}$ in our studies) was the second most frequently isolated race in Ontario, and this concurs with previous reports from other corn growing countries (Ferguson and Carson 2007; GalianoCarneiro and Miedaner 2017; Leonard 1993; Raymundo and Hooker 1981; Turner and Johnson 1980; Welz and Geiger 2000). The widespread distribution of races 1 and $1 \mathrm{~N}$ in the current study is most likely the result of selection pressure owing to a greater area being planted to corn hybrids with $\mathrm{Htl}$ and $\mathrm{Htnl}$ resistance genes in Ontario, similar to observations reported from the United States by Ferguson and Carson (2007). Population of race 0 ( 0 and $\mathrm{M}$ in our studies) declined from $22 \%$ in 2006-07 (Zhu et al. 2010) to $12 \%$ in this study (2012 to 2016), possibly because of the more frequent use of Htl and Htnl genes in the commercial hybrids (GalianoCarneiro and Miedaner 2017). Because nine races (2, 3, 12, 3M, $12 \mathrm{~N}, 13 \mathrm{M}, 13 \mathrm{~N}, 12 \mathrm{MN}$, and $123 \mathrm{MN}$ ) were less frequently recovered, this suggests the resistance genes $\mathrm{Ht} 2$ and $\mathrm{Ht} 3$ may not have been widely deployed in the commercial hybrids in Ontario, resulting in less selection pressure, less mutation, and less sexual recombination. Similarly, Henekamp et al. (2014) reported a low frequency of races 2, 12, 3, 23, 3N, 123, and $23 \mathrm{~N}$ in Central Europe.

Fewer isolates (6 to $12 \%$ ) from the Et population tested were virulent on $H t 2$ or $H t 3$ compared with Htl, Html, and Htnl (64 to 81\%) across all four regions (Table 6). Low frequency of races with virulence on $\mathrm{Ht} 2$ and $\mathrm{Ht} 3$ has also been reported from the United States and elsewhere (Dong et al. 2008; Fallah Moghaddam and Pataky 1994; Ferguson and Carson 2004; Ji et al. 2013; Jordan et al. 1983; Lipps and Hite 1982; Weems and Bradley 2018). It is difficult to explain the low frequency of isolates virulent on these $H t$ genes despite their presence across years and regions sampled. One possible explanation is that $H t 2$ and $H t 3$ have not been widely deployed in

Table 5. Frequency of Exserohilum turcicum isolates virulent on each $\mathrm{Ht}$ resistance gene within and across years ${ }^{\mathrm{a}}$

\begin{tabular}{|c|c|c|c|c|c|c|}
\hline \multirow[b]{2}{*}{ Year } & \multirow{2}{*}{$\begin{array}{c}\text { Number of } \\
\text { isolates }\end{array}$} & \multicolumn{5}{|c|}{ Number of virulent isolates on each $\mathrm{Ht}$ gene } \\
\hline & & Ht1 & $\mathrm{Ht2}$ & Ht3 & Html & HtnI \\
\hline 2012-13 & 151 & $149(99)$ & $10(7)$ & $16(11)$ & $129(85)$ & $85(56)$ \\
\hline 2014 & 175 & $44(82)$ & $11(6)$ & $15(9)$ & $140(80)$ & $117(67)$ \\
\hline 2015 & 184 & $148(80)$ & $8(4)$ & $25(14)$ & $80(43)$ & $128(70)$ \\
\hline 2016 & 167 & $110(66)$ & $13(8)$ & $22(13)$ & $86(51)$ & $104(62)$ \\
\hline All years & 677 & $551(81)$ & $42(6)$ & $78(12)$ & $435(64)$ & $434(64)$ \\
\hline
\end{tabular}

a The number in parentheses is the percentage of total isolates virulent on each $H t$ resistance gene. commercial hybrids because the gene (Shtl) that is often associated with $H t 2$ is known to suppress the transfer to elite germplasm through backcrossing programs (Ceballos and Gracen 1989) and because of variation in resistance expression under different environmental temperatures and light intensities (Ferguson and Carson 2004; Leath et al. 1990; Thakur et al. 1989b).

Similar symptoms on the corn plants with $\mathrm{Ht} 2$ or $\mathrm{Ht} 3$ resistance genes in this study confirm the earlier finding of Welz (1998), who reported that it can be difficult to distinguish the phenotype of the plants with genes $\mathrm{Ht} 2$ or $\mathrm{Ht} 3$ because the virulence to these genes appears to be inherited by the same single gene. The presence of virulence to $H t 2$ without virulence to $H t 3$ or vice versa reported in this study has also been reported in earlier studies (Dong et al. 2008; Fallah Moghaddam and Pataky 1994; Muiru et al. 2010; Ogliari et al. 2005). Ht2 and $\mathrm{Ht} 3$ resistance genes have been mapped and found on different parts of the chromosome, Ht2 mapped on the long arm of chromosome 8 (bin 8.06) (Zaitlin et al. 1992) and $\mathrm{Ht3}$ on bin 7.04 (Zhang et al. 2014), which shows that virulence to $\mathrm{Ht} 2$ and $\mathrm{Ht} 3$ may not be inherited by the same single gene.

Despite all the available information, it is hard to explain the exact cause of genetic variation in Et populations over time and space and their virulence without knowing the degree of deployment of $\mathrm{Ht}$ resistance genes in commercial hybrids. Unfortunately, the information on the deployment of resistance genes is not available for most of the commercial hybrids developed and marketed by private companies; however, there are a few general reports available on the use of $\mathrm{HtI}$ and Htnl for NCLB management in North America, which has presumably led to the appearance of virulent races against these genes (Galiano-Carneiro and Miedaner 2017; Welz and Geiger 2000).

The increasing incidence of NCLB across the Ontario Corn Belt in last 10 years may be owing to changes in pathogen population, agronomic practices, climate, and reduced host resistance in the currently cultivated hybrids, as had been reported earlier for other corn growing regions of the world (Galiano-Carneiro and Miedaner 2017; Munkvold et al. 2008; Wise and Mueller 2011). This study has shown that the race structure of $E t$ populations varies considerably (more frequent and widespread $H t 1, H t n l$, and $H t m l$ virulent isolates compared with $H t 2$ and $H t 3$ ), and consequently both quantitative resistance and qualitative resistance should be used for the effective management of NCLB in Ontario. Qualitative resistance is preferred because it is easier and faster to deploy in a breeding program by backcrossing. Quantitative resistances need to be accumulated by population improvements followed by inbred selections, which takes much more time, land, and economic resources. However, qualitative resistance is often not effective over a long period in environments with high disease severity, because new virulent races develop quickly (Welz and Geiger 2000). Different methods such as the use of three-way or double-cross hybrids with inbreds having different resistance genes (McDonald and Linde (2002), pyramiding several $\mathrm{Ht}$ genes in the same cultivar (Galiano-Carneiro and Miedaner 2017), recurrent selection (Ayiga-Aluba et al. 2015; Carson 2006; Ceballos et al. 1991; Ribeiro et al. 2016), and regular analyses of race distribution/abundance using available molecular markers (Mideros et al. 2018) to select genes that are still effective in the target area have been suggested to improve and prolong the durability of qualitative resistance. Currently available $\mathrm{Ht}$ resistance genes $\mathrm{Ht} 2, \mathrm{Ht} 3$, $H t P, H t N B, h t 4$, and $r t$, which have not been widely used, may be

Table 6. Frequency of Exserohilum turcicum isolates virulent on each $H t$ resistance gene within and across regions ${ }^{\mathrm{a}}$

\begin{tabular}{|c|c|c|c|c|c|c|}
\hline \multirow[b]{2}{*}{ Region } & \multirow[b]{2}{*}{ Number of isolates } & \multicolumn{5}{|c|}{ Number of virulent isolates on each $H t$ resistance gene } \\
\hline & & Ht1 & Ht2 & $H+3$ & Htm1 & Htn1 \\
\hline Central Ontario & 14 & $13(93)$ & $1(7)$ & $4(29)$ & $11(79)$ & $10(71)$ \\
\hline Eastern Ontario & 264 & $196(74)$ & $16(6)$ & $24(9)$ & $152(58)$ & $138(52)$ \\
\hline Southern Ontario & 292 & $241(83)$ & $18(6)$ & $38(13)$ & $206(71)$ & $201(69)$ \\
\hline Western Ontario & 107 & $101(94)$ & 7 (7) & $12(11)$ & $66(62)$ & $85(79)$ \\
\hline All regions & 677 & $551(81)$ & $42(6)$ & $78(12)$ & $435(64)$ & $434(64)$ \\
\hline
\end{tabular}

a The number in parentheses is the percentage of total isolates virulent on each $H t$ resistance gene. 
introgressed by multiple backcrosses into new elite germplasm for use in breeding programs to develop new hybrids for NCLB management (Galiano-Carneiro and Miedaner 2017; Welz and Geiger 2000). It is difficult to predict whether the use of currently available $H t$ resistance genes could be helpful to improve management of NCLB for the long term; however, there is potential that this may advance disease management. There is a need to follow a comprehensive approach including the search for new resistance genes, new methods to introgress them into breeding material, and identifying molecular markers to study the race distribution to deploy the genes that are effective in the target area.

It is important to understand the occurrence and distribution of $E t$ races across Ontario in plant breeding for screening resistance genes and also for developing disease risk management strategies in corn production. Based on the information generated in the current study, growers, potentially, may be able to select hybrids with multiple $H t$ resistance genes to reduce the risk of disease, if it was known what resistance genes were contained in the hybrids. In the current study, races $1,1 \mathrm{~N}, 1 \mathrm{M}$, and $1 \mathrm{MN}$ were more frequent compared with other identified races. This means that hybrids with Htl, Htm l, and Htnl genes may have a greater risk of NCLB across the province; therefore, these three genes should be used less frequently in NCLB resistance breeding. More work to introgress other Et resistance genes in the breeding program will increase the diversity and improve and prolong the durability of qualitative resistance.

\section{Acknowledgments}

We thank Tharcisse Barasubiye, manager, Fungal Culture Collection, for confirming the identity of Exserohilum turcicum isolates and Goulet Benoit, research assistant, for assigning DAOMC numbers to the fungal cultures deposited in the culture collection. We also thank our grower cooperators, various seed companies (Hyland Seeds, Maizex Seeds, Mycogen Seeds, Pioneer Hi-Bred, and Pride Seeds) and the Ontario Corn Committee for access to their fields as well as AAFC ORDC and Ontario Ministry of Agriculture, Food and Rural Affairs staff that helped in one way or another on this project.

\section{Literature Cited}

Adipala, E., Lipps, P. E., and Madden, L. V. 1993. Occurrence of Exserohilum turcicum on maize in Uganda. Plant Dis. 77:202-205.

Ayiga-Aluba, J., Edema, R., Tusiime, G., Asea, G., and Gibson, P. 2015. Response to two cycles of $\mathrm{S} 1$ recurrent selection for turcicum leave blight in an open pollinated maize variety population (Longe 5). Adv. App. Sci. Res. 6:4-12.

Bergquist, R. R., and Masias, O. R. 1974. Physiologic specialization in Trichometasphaeria turcica f. sp. zeae and T. turcica f. sp. sorghi in Hawaii. Phytopathology 64:645-649.

Bunkoed, W., Kasam, S., and Chaijuckam, P. 2014. Sexual reproduction of Setosphaeria turcica in natural corn fields in Thailand. Kasetsart J. 48:175-182.

Carson, M. L. 1995. A new gene in maize conferring the "chlorotic halo" reaction to infection by Exserohilum turcicum. Plant Dis. 79:717-720.

Carson, M. L. 2006. Response of a maize synthetic to selection for components of partial resistance to Exserohilum turcicum. Plant Dis. 90:910-914.

Ceballos, H., Deutsch, J. A., and Gutierrez, H. 1991. Recurrent selection for resistance to Exserohilum turcicum in eight subtropical maize populations. Crop Sci. 31:964-971.

Ceballos, H., and Gracen, V. E. 1989. A dominant inhibitor gene inhibits the expression of Ht2 against Exserohilum turcicum race 2 in corn inbred lines related to B14. Plant Breed. 102:35-44.

Dong, J., Fan, Y., Gui, X., An, X., Ma, J., and Dong, Z. 2008. Geographic distribution and genetic analysis of physiological races of Setosphaeria turcica in Northern China. Am. J. Agric. Biol. Sci. 3:389-398.

Fallah Moghaddam, P., and Pataky, J. K. 1994. Reactions of isolates from matings of races 1 and 23N of Exserohilum turcicum. Plant Dis. 78:767-771.

Ferguson, L. M., and Carson, M. L. 2004. Spatial diversity of Setosphaeria turcica sampled from the eastern United States. Phytopathology 94:892-900.

Ferguson, L. M., and Carson, M. L. 2007. Temporal variation in Setosphaeria turcica between 1974 and 1994 and origin of races 1, 23, and 23N in the United States. Phytopathology 97:1501-1511.

Galiano-Carneiro, A. L., and Miedaner, T. 2017. Genetics of resistance and pathogenicity in the maize/Setosphaeria turcica pathosystem and implications for breeding. Front. Plant Sci. 8:1490.

Gevers, H. O. 1975. A new major gene for resistance to Helminthosporium turcicum leaf blight of maize. Plant Dis. Rep. 59:296-299.

Gianasi, L., de Castro, H. A., and da Silva, H. P. 1996. Raças fisiológicas de Exserohilum turcicum identificadas em regiões produtoras de milho no Brasil, Safra 93/94. Summa Phytopathol. 22:214-217.

Groth, J. V., and Roelfs, A. P. 1987. The concept and measurement of phenotypic diversity in Puccinia graminis on wheat. Phytopathology 77:1395-1399.
Henekamp, H., Kessel, B., Koopmann, B., and von Tiedemann, A. 2014. Regional effectiveness of race specific resistances to Exserohilum turcicum, the causal agent of Turcicum leaf blight in maize. Meeting of the Diseases Working Group in Cereal and Corn. J. Kulturpflanzen 66:215.

Hilu, H. M., and Hooker, A. L. 1964. Host-pathogen relationship of Helminthosporium turcicum in resistant and susceptible corn seedlings. Phytopathology 54:570-575.

Hooker, A. L. 1961. A new type of resistance in corn to Helminthosporium turcicum. Plant Dis. Rep. 45:780-781.

Hooker, A. L. 1963. Inheritance of chlorotic-lesion resistance to Helminthosporium turcicum in seedling corn. Phytopathology 53:660-662.

Hooker, A. L. 1977. A second major gene locus in corn for chlorotic-lesion resistance to Helminthosporium turcicum. Crop Sci. 17:132-135.

Hooker, A. L. 1981. Resistance to Helminthosporium turcicum from Tripsacum floridanum incorporated into corn. Maize Genet. Coop. Newsl. 55:87-88.

Ishfaq, A., Dar, Z. A., Lone, A., Ali, G., Gazal, A., Hamid, B., and Mohidin, F. A. 2014. Disease reaction studies of maize (Zea mays L.) against turcicum leaf blight involving indigenously identified cytosterile source. Afr. J. Microbiol. Res. 8:2592-2597.

Ji, L. J., Li, Q. S., Wang, L. S., Li, C. C., and Kong, L. X. 2013. Composition of physiological races of Exserohilum turcicum in Hebei Province. J. Maize Sci. 21:125-127, 133.

Jindal, K. K., Reid, L. M., Tenuta, A. U., Woldemariam, T., Zhu, X., and Kotuluk, G. 2016. Status of corn diseases in Ontario, 2015 crop season. Can. Plant Dis. Surv. 96:102-108.

Jindal, K. K., Reid, L. M., Tenuta, A. U., Woldemariam, T., Zhu, X., and Kotuluk, G. 2017. Status of corn diseases in Ontario, 2016 crop season. Can. Plant Dis. Surv. 97:154-160.

Jindal, K. K., Reid, L. M., Tenuta, A. U., Woldemariam, T., Zhu, X., and Kotuluk, G. 2018. Status of corn diseases in Ontario, 2017 crop season. Can. Plant Dis. Surv. 98:152-159.

Jordan, E. G., Perkins, J. M., Schell, R. A., and Pedersen, W. L. 1983. Occurrence of race 2 of Exserohilum turcicum on corn in the central and eastern United States. Plant Dis. 67:1163-1165.

Kloppers, R., and Tweer, S. 2009. Northern corn leaf blight fact sheet. PANNA Seed (Pty) Ltd. https://www.plantwise.org/FullTextPDF/2011/20117800335. pdf.

Krausz, J. P., Fredericksen, R. A., Rodrigues-Ballesteros, O. R., Odvody, G. N., and Kaufman, H. W. 1993. Epidemic of northern corn leaf blight in Texas in 1992. Plant Dis. 77:1063.

Leath, S., Thakur, R. P., and Leonard, K. J. 1990. Variation in expression of monogenic resistance in corn to Exserohilum turcicum race 3 under different temperature and light regimes. Phytopathology 80:309-313.

Leonard, K. J. 1993. Durable resistance in the pathosystems: Maize-Northern and southern leaf blights. Pages 99-114 in: Durability of disease resistance. T. Jacobs and J. E. Parlevliet, eds. Kluwer Academic Publishers, Dordrecht, Netherlands.

Leonard, K. J., Levy, Y., and Smith, D. R. 1989. Proposed nomenclature for pathogenic races of Exserohilum turcicum on corn. Plant Dis. 73:776-777.

Lipps, P. E., and Hite, R. E. 1982. Exserohilum turcicum virulent on corn with the Ht resistance gene in Ohio. Plant Dis. 66:397-398.

Mallowa, S. O., Esker, P. D., Paul, P. A., Bradley, C. A., Chapara, V. R., Conley, S. P., and Robertson, A. E. 2015. Effect of maize hybrid and foliar fungicides on yield under low foliar disease severity conditions. Phytopathology 105:1080-1089.

McDonald, A. B., and Linde, C. 2002. Pathogen population genetics, evolutionary potential and durable resistance. Annu. Rev. Phytopathol. 40:349-379.

Mideros, S. X., Chung, C.-L., Wiesner-Hanks, T., Poland, J. A., Wu, D., Fialko, A. A., Turgeon, B. G., and Nelson, R. J. 2018. Determinants of virulence and in vitro development colocalize on a genetic map of Setosphaeria turcica. Phytopathology 108:254-263.

Mueller, D. S., Wise, K. A., Sisson, A. J., Allen, T. W., Bergstrom, G. C., Bosley, D. B., Bradley, C. A., Broders, K. D., Byamukama, E., Chilvers, M. I., Collins, A., Faske, T. R., Friskop, A. J., Heiniger, R. W., Hollier, C. A., Hooker, D. C., Isakeit, T., Jackson-Ziems, T. A., Jardine, D. J., Kelly, H. M., Kinzer, K., Koenning, S. R., Malvick, D. K., McMullen, M., Meyer, R. F., Paul, P. A., Robertson, A. E., Smith, D. L., Tande, C. A., Tenuta, A. U., Vincelli, P., and Warner, F. 2016. Corn yield loss estimates due to diseases in the United States and Ontario, Canada, from 2012 to 2015. Plant Health Prog. 17: 211-222.

Muiru, W. M., Koopmann, B., Tiedemann, A. V., Mutitu, E. W., and Kimenju, J. W. 2010. Race typing and evaluation of aggressiveness of Exserohilum turcicum isolates of Kenya, German and Austrian origin. World J. Agric. Sci. 6:277-284.

Munkvold, G. P., Doerge, T., and Bradley, C. 2008. IPM is still alive for corn leaf diseases: Look before you spray. In: Proceedings of the 62nd Annual Corn Sorghum Research Conference, Chicago. CD-ROM, American Seed Trade Association, Alexandria, VA.

Nwanosike, M. R. O., Mabagala, R. B., and Kusolwa, P. M. 2013. Effect of northern leaf blight (Exserohilum turcicum) severity on yield of maize (Zea mays L.) in Morogoro, Tanzania. Int. J. Sci. Res. (Ahmedabad) 4:466-474.

Ogliari, J. B., Guimarães, M. A., Geraldi, I. O., and Camargo, L. E. A. 2005. New resistance genes in the Zea mays-Exserohilum turcicum pathosystem. Genet. Mol. Biol. 28:435-439. 
Pataky, J. K., Perkins, J. M., and Leath, S. 1986. Effects of qualitative and quantitative resistance on the development and spread of northern leaf blight of maize caused by Exserohilum turcicum races 1 and 2. Phytopathology 76:1349-1352.

Pieczarka, D. J. 1980. A new race of Helminthosporium turcicum and reaction of sweet corn hybrids to the pathogen. Proc. Fla. State Hortic. Soc. 93:281-283.

Pierce, P. 2016. Hybrids resistant to northern corn leaf blight. No-Till Farmer. https://www.no-tillfarmer.com/articles/5451-hybrids-resistant-to-northern-cornleaf-blight.

Raymundo, A. D., and Hooker, A. L. 1981. Measuring the relationship between northern corn leaf blight and yield losses. Plant Dis. 65:325-327.

Ribeiro, R. M., Junior, A. T. A., Penal, G. F., Vivas, M., Kurosawa, R. N., and Goncalves, L. S. A. 2016. History of northern corn leaf blight disease in the seventh cycle of recurrent selection of an UENF-14 popcorn population. Acta Sci. Agron. 38:447-455.

Robbins, W. A., Jr., and Warren, H. L. 1993. Inheritance of resistance to Exserohilum turcicum in PI 209135 'Mayorbela' variety of maize. Maydica 38:209-213.

Schechert, A. W., Welz, H. G., and Geiger, H. H. 1999. QTL for resistance to Setosphaeria turcica in tropical African maize. Crop Sci. 39:514-523.

Simcox, K. D., and Bennetzen, J. L. 1993. The use of molecular markers to study Setosphaeria turcica resistance in maize. Phytopathology 83:1326-1330.

Simcox, K. D., Pedersen, W. L., and Nickrent, D. L. 1993. Isozyme diversity in Setosphaeria turcica. Can. J. Plant Pathol. 15:91-96.

Smith, D. R., and Kinsey, J. G. 1980. Further physiologic specialization in Helminthosporium turcicum. Plant Dis. 64:779-781.

Thakur, R. P., Leonard, K. J., and Jones, R. K. 1989a. Characterization of a new race of Exserohilum turcicum virulent on corn with resistance gene $H t \mathrm{~N}$. Plant Dis. 73:151-155.

Thakur, R. P., Leonard, K. J., and Leath, S. 1989b. Effects of temperature and light on virulence of Exserohilum turcicum on corn. Phytopathology 79:631-635.

Turner, M. T., and Johnson, E. R. 1980. Race of Helminthosporium turcicum not controlled by $\mathrm{Ht}$ genetic resistance in corn in the American corn belt. Plant Dis. 64:216-217.

Vieira, R. A., Scapim, C. A., Moterle, L. M., Tessmann, D. J., Conrado, T. V., and Amaral, A. T., Jr. 2009. Diallel analysis of leaf disease resistance in inbred Brazilian popcorn cultivars. Genet. Mol. Res. 8:1427-1436.
Wang, H., Xiao, Z. X., Wang, F. G., Xiao, Y. N., Zhao, I. R., Zheng, Y. L., et al. 2012. Mapping of $H t N B$, a gene conferring non-lesion resistance before heading to Exserohilum turcicum (Pass.), in a maize inbred line derived from the Indonesian variety Bramadi. Genet. Mol. Res. 11:2523-2533.

Wang, L. Z., Kang, Z. Y., Wu, J. Z., Wu, Y. X., Mao, Z. C., and He, Y. Q. 2011. Identification of physiological races and analysis of mating type of Setosphaeria turcica in Yunnan province. J. Huazhong Agric. Univ. 30:187-192.

Wang, P., Souma, K., Kobayashi, Y., Iwabuchi, K., Sato, C., and Masuko, T. 2010. Influences of northern leaf blight on corn silage fermentation quality, nutritive value and feed intake by sheep. Anim. Sci. J. 81:487-493.

Weems, J. D., and Bradley, C. A. 2018. Exserohilum turcicum race population distribution in the north central United States. Plant Dis. 102:292-299.

Welz, H. G. 1998. Genetics and epidemiology of the pathosystem Zea mays/ Setosphaeria turcica. Habilitation thesis, University of Hohenheim/ShakerVerlag, Stuttgart/Aachen, Germany.

Welz, H. G., and Geiger, H. H. 2000. Genes for resistance to northern corn leaf blight in diverse maize populations. Plant Breed. 119:1-14.

Welz, H. G., Wagner, R., and Geiger, H. H. 1993. Virulence variation in Setosphaeria turcica populations collected from maize in China, Mexico, Uganda, and Zambia. Phytopathology 83:1356.

Windes, J. M., and Pedersen, W. L. 1991. An isolate of Exserohilum turcicum virulent on maize inbreds with resistance gene HtN. Plant Dis. 75:430.

Wise, K., and Mueller, D. 2011. Are fungicides no longer just for fungi? An analysis of foliar fungicide use in corn. APSnet feature article. doi:10.1094/ APSnetFeature-2011-0531.

Zaitlin, D., DeMars, S. L., and Gupta, M. 1992. Linkage of a second gene for NCLB resistance to molecular markers in maize. Maize Genet. Coop. Newsl. 66:69-70.

Zhang, X. L., Si, B. W., Fan, C. M., Li, H. J., and Wang, X. M. 2014. Proteomics identification of differentially expressed leaf proteins in response to Setosphaeria turcica infection in resistant maize. J. Integr. Agric. 13:789-803.

Zhu, X., Reid, L. M., and Woldemariam, T. 2010. Pathogenic races of Exserohilum turcicum on corn in Ontario and Quebec. Page 15 in: Proceedings of 2010 Joint Annual Meeting of Canadian Phytopathological Society with the Pacific Division of the American Phytopathological Society. June 20-23, 2010 University of British Columbia, Vancouver, BC. 